\title{
FOREIGN TRADE POLICY AND APPARATUS OF THE PEOPLE'S REPUBLIC OF CHINA
}

\author{
KENNETH WANG*
}

\section{INTRODUCTION}

As an aftermath of the Opium War of 1840-1842 and the subsequent military and diplomatic setbacks at the hand of foreign powers, China was forced to open its doors to foreign traders on terms calculated to give every possible advantage to those traders at the expense of China's domestic economy and industry. Under treaties imposed upon China, foreign traders were permitted to navigate Chinese inland waters without restriction and to operate factories, banks, insurance companies, and other commercial enterprises in China. These treaties allowed foreign powers to control such governmental functions as customs and postal services, and granted foreign nationals in China immunity from local jurisdiction. As a result of these treaties, all of China was open to foreign exploitation, making the development of domestic industry extremely difficult. For almost a century, China remained in this semi-colonial status, and its economy gradually but steadily deteriorated to the point of total collapse before the communist take-over in 1949.

It was against this background that the foreign trade policy of the new regime was formulated. It is small wonder that the People's Republic of China has adopted a very stringent protective trade policy, and that it emphasizes the need for domestic industrialization and strict control of import and export activities. It is also easy to understand why contemporary China has not welcomed with open arms foreign traders who desire to operate within its territory.

Foreign Trade Policy

\section{A. Elements of Current Policy}

At the United Nations Conference on Trade and Development held in 1972 in Santiago, Chile, Chou Hua-min, chief of the Chinese delegation and Vice-Minister of Foreign Trade, articulated the basic principles of foreign trade adhered to by the People's Republic of China. This recent policy statement made by a responsible government representative duly accredited to an international conference dealing specifically with trade and development requires careful analysis to gain a clear understanding of the regime's foreign trade policy. The significance of this speech was highlighted by an article in Jen min jih pao, the official organ of the Chinese Communist Party. The headline of this article read: "Chief of Delegation Chou Hua-min spoke at the plenary

*Professor of Law, St. John's University. 
session of the third meeting of United Nations Conference on Trade and Development explaining our country's principled position on the international economy and trade relations."1

Shorn of its political rhetoric, the speech contains four points. These are: (1) a realistic assessment of China's economic strength, including admissions that the level of economic development is still not high and that China, together with the overwhelming majority of countries in Asia, Africa, and Latin America, is still a developing country; (2) a reaffirmation of the firm conviction of the Chinese people that political independence and self-determination are prerequisites to economic development, that economic development is imperative to safeguarding independence, and that self-reliance, by using the country's own manpower and resources, is the key to economic development; (3) an expression of China's willingness, and its recognition of the need, to promote trade with all other countries of the world on the basis of equality and mutual benefit; and (4) a reiteration of the five principles originally expounded in 1955 at the Bandung Conference as the basis for regulating relations among nations, and China's firm belief that all international economic and trade relations should be governed by these five principles. ${ }^{2}$

It should be noted that, in substance, this speech reflects the basic policy position consistently held by the People's Republic with regard to economic relations with other countries. Since the People's Republic gained control of Mainland China in 1949, similar pronouncements have been made periodically by its leaders. It has always maintained that it is ready, willing, and able to trade with other countries on the basis of equality and mutual benefit. As early as 1949, Chairman Mao Tse-tung said:

"We want to do business." Quite right, business will be done. We are against no one except the domestic and foreign reactionaries who hinder us from doing business. Everybody should know that it is none other than the imperialists and their running dogs, the Chiang Kai-shek reactionaries, who hinder us from doing business and also from establishing diplomatic relations with foreign countries. When we have beaten the internal and external reactionaries by uniting all domestic and international forces, we shall be able to do business and establish diplomatic relations with all foreign countries on the basis of equality, mutual benefit and mutual respect for territorial integrity and sovereignty. ${ }^{3}$

The Common Program promulgated in 1949, on the eve of the establishment of the P.R.C., made it clear that China's foreign trade policy would be influenced by a variety of considerations-economic, military, and political. Economically, foreign trade was to play an important role in the promotion of internal socialist development. Article 37 of the Common Program provides that

\footnotetext{
'Jen min jih pao (People's Daily), Apr. 21, 1972.

2 The Bandung Conference, held in April of 1955, was attended by various African and Asian states. The five principles it adopted are: (1) respect for the sovereignty and territorial integrity of all states, (2) non-aggression, (3) non-intervention in the internal affairs of another state, (4) equality and mutual benefit, and (5) peaceful coexistence.

3 Mao Tse-tung, On the People's Democratic Dictatorship, in 4 Selected Works of Mao Tse-tung 416 (1961).
} 
[c]ontrol shall be exercised over foreign trade and a protective trade policy shall be adopted.... State owned trading organizations shall assume the responsibility of adjusting supply and demand, stabilizing commodity prices and assisting the people's cooperatives. The People's Government shall adopt the measures necessary to encourage the people in saving, to facilitate remittances from overseas Chinese, and to channel into industry and other enterprises of production, all idle capital of society and commercial capital which is not beneficial to the national welfare and/or to the people's livelihood. ${ }^{4}$

The essence of this provision is that, through centralized control, the government will endeavor to channel all available capital into production and development. Pursuant to this basic policy, the government of China has repeatedly stressed the importance of making every effort to increase the importation of industrial machinery and equipment, while exporting nonessential or surplus commodities that are saleable on the world market in exchange for goods that are essential for its internal economic development.

In 1950, one year after the establishment of the People's Republic of China, the Government Administration Council (termed the State Council under the 1954 Constitution) of the Central People's Government promulgated the Provisional Regulations for the Control of Foreign Trade. ${ }^{5}$ Those regulations place the control of foreign trade and the implementation of a stringent protective trade policy in the hands of the Bureau of Foreign Trade and its branch offices, under the direction of the Ministry of Trade. ${ }^{6}$ Domestic firms and factories engaged in import and export trade, foreign traders engaged in import and export trade in China, and agents of foreign commercial firms are required to register with the Bureau of Foreign Trade. ${ }^{7}$ All import and export transactions must be approved and licensed by the Bureau of Foreign Trade. ${ }^{8}$

The Provisional Regulations for the Control of Foreign Trade also prescribe penalties for violations of their provisions or any other rules and regulations pertaining to foreign trade. Local branch offices of the Bureau of Foreign Trade may impose on violators such penalties as "education," "warning," or "sus" pension of business." Where serious offenses are involved, violators may be referred to judicial organs for "punishment according to law."9 Commodities that are subject to testing and inspection under government regulations must be submitted by the importer or exporter to the Commodities Testing and Inspection Bureau for testing and inspection. Import and export of such commodities is permitted only upon procurement of a certificate of testing and inspection. ${ }^{10}$

\footnotetext{
41 Chung yang Jen min cheng fu fa ling hui pien (Collection of Laws and Decrees of the Central People's Government) 22 (1952) [hereinafter cited as FLHP].

${ }^{5}$ See Provisional Regulations for the Control of Foreign Trade, in 1 FLHP 337 (1952).

${ }^{6} I d$. arts. $1 \& 2$.

${ }^{7} I d$. arts. 3 \& 4. See also Rules Governing the Application for Registration of Import and Export Factories and Firms, art. 3, in 2 CHUNG YANG TS'AI CHING CHENG TS'E FA LING HUI PIEN (Collection of Financial and Economic Policies, Laws, and Decrees of the Central Government) 896 (1951).

${ }^{8}$ See Provisional Regulations for the Control of Foreign Trade, art. 7, in 1 FLHP $337-38$ (1952).

${ }^{9} I d$. art. 11 .

${ }^{10}$ See Detailed Rules for the Implementation of the Provisional Regulations for the Control of Foreign Trade, art. 8, in 2 Chung yang tS'AI ching cheng TS'E FA LING HuI PIEN 890 (1951).
} 
This stringent protective trade policy under strict central control is the cornerstone of China's foreign trade. In 1956, Yeh Chi-chuang, then Minister of Foreign Trade, made this point abundantly clear in a speech at a meeting of the Eighth National Congress of the Chinese Communist Party. He said, "[e]xport is to make possible the import of various essential materials for our development in general and the development of our heavy industry in particular."11 He went on to say that foreign trade agencies should be given priority to contract for the acquisition of export commodities, especially those that were either in short supply or of superior quality. ${ }^{12}$

Insofar as China's basic economic aims are concerned, this protective trade policy has been quite successful. In 1959, Chou En-lai, in his article to commemorate the ten th anniversary of the founding of the People's Republic, said:

During the past ten years our foreign trade has also undergone enormous changes. Since the victory of the Chinese revolution in 1949, we have recaptured the control of our customs from the hands of the imperialists. In the area of import and export trade, the long-standing phenomenon of imports exceeding exports has begun to turn around. In 1958, the total volume of exports and imports increased 2.1 times compared with that of 1950. Of this, imports increased 1.9 times while exports increased 2.3 times, showing a basic balance between imports and exports. Contrary to the situation that existed prior to liberation when imports consisted primarily of consumer goods, more than 90 per cent of our imports consisted of machinery, equipment, raw materials and other materials for production. This has produced a tremendous impact on the economic development of our country. ${ }^{13}$

Military considerations have also influenced the foreign trade policy of China. Since the outbreak of the Korean conflict in 1950, and as a reaction to the United States military posture in Asia pursuant to both the Truman Declaration and the Dulles Doctrine, the Chinese have imported large quantities of metal, hardware, rubber, petroleum, and transportation equipment in order to strengthen their nation's military preparedness. One of the prime purposes of China's first five-year plan was to develop heavy industry which would aid in improving production of military hardware for national defense. To this end, large quantities of uranium and other materials were imported from Africa and elsewhere.

Chinese leaders believe that foreign trade must play an important role in furthering the political objectives of the state. One of the major political objectives of the People's Republic of China has been to gain diplomatic recognition from as many countries as possible. Foreign trade has been used as one of the avenues to achieve this aim. It has been thought that once trade relations were established such contacts would gradually evolve into diplomatic relations. Substantial economic assistance was extended to many developing countries in Africa, Asia, and Latin America to enable them to purchase Chinese goods so that trade relations with those countries could be established. All of

\footnotetext{
11 Jen min jih pao, Sept. 28, 1956.

12 Id.

1310 Chung hua Jen Min Kung ho KUO Fa KUEI hui PIEN (Collection of LAws and Regulations of the People's Republic of China) 28-29 (160) [hereinafter cited as FKHP].
} 
these activities were intended to serve important political purposes of China. In an article entitled International Economic Cooperation and Peaceful Coexistence, Chi Ch'ao-ting, then Secretary General of the China Council for the Promotion of International Trade (CCPIT), said:

For a socialist country, the purpose of production is not to make profit, but rather to meet the needs of developing the domestic economy and of improving the day-to-day economic and cultural life of the people. The domestic market of a socialist country is expanding continuously along with the increase in production and the improvement of the living standard of the people. Hence, the purpose of export by a socialist country is not to grab market and to pursue profit but rather to get in exchange for such export commodities that are necessary to meet the needs of domestic economic development and the people's livelihood. In addition, whenever necessary, certain commodities will be set aside to help those countries friendly to us, especially those developing countries in need of such help for their industrialization.... ${ }^{14}$

Certain events stand out as typical instances of the use of trade to achieve political goals. In 1951, when India was facing a severe famine, China supplied India with a large quantity of rice under a barter arrangement. According to the June 8, 1952, issue of Jen min jih pao, an agreement was signed in the fall of 1951 between China and India which stated that China was to supply India with 66,000 tons of rice and 442,000 tons of sorghum. On May 26, 1952, a second agreement was signed for 100,000 tons of rice, and on October 13, 1952, a third agreement was signed for 50,000 tons of rice. From 1952, the volume of trade between the P.R.C. and India increased very rapidly until 1956, when it reached a plateau. It seems likely that this trade had considerable influence on India's position in the international arena in regard to matters affecting the P.R.C.

The purchase by China, in 1952, of large quantities of rubber from Ceylon at a price considerably higher than that prevailing in the world market and at a time when Ceylon was having difficulties finding buyers for this product led to a substantial increase in trade between the two countries during the ensuing years. From an economic standpoint, this trade helped China acquire an essential commodity which it found difficult to obtain elsewhere because of a Western embargo. From a political standpoint, it obviously had considerable effect upon the attitudes of both the government and the people of Ceylon toward the P.R.C. This was particularly true with respect to the question of diplomatic recognition. ${ }^{15}$

While China was promoting trade with, and extending economic aid to, certain countries to achieve its political objectives, it was also using foreign trade as a weapon against other countries for political reasons. For example, a trade agreement between China and Finland expressly prohibited the use of ships of American registry to transport goods in Sino-Finnish trade. ${ }^{16}$

\footnotetext{
141957 Tui wai mao i (Selected Essays on Foreign Trade) 115.

${ }^{15}$ Another example of the use of trade to achieve political purposes was the 1954 FrenchChinese wheat deal. In that year, France sold one million tons of wheat to China, in a transaction which France found economically profitable. This transaction helped pave the way toward French diplomatic recognition of the People's Republic of China.

162 Chung hUA JEN MIN KUNG ho KUO T'IAO YÜEH GHI (Collection of Treaties of ThE People's Republic of China) 372 (1957).
} 
Similar restrictions can be found in several subsequent trade agreements between China and other countries. However, as a result of President Nixon's visit to China in 1972, it is believed that henceforth economic, as opposed to political, considerations will probably be given greater weight in Chinese foreign trade transactions.

\section{B. Evolution of Current Policy}

The evolution of Chinese foreign trade policy and the development of trade with various countries may be divided into two major periods. The first is the period from 1950 to 1959 , which may be characterized as one of heavy reliance upon the U.S.S.R. and other communist countries-a period of "leaning to one side."17 During this period, countries that never had a significant share in the China market suddenly became important trading partners of the People's Republic, while countries which had traditionally dominated the scene were no longer visible. This development was attributable partly to Chinese policy and partly to the inability of Western traders to adapt emotionally to the changed circumstances. The United Nations economic sanctions, the American trade embargo, the Foreign Assets Control Regulations, and the Export Control Regulations of the United States, as well as the COCOM and CHINCOM arrangements, ${ }^{18}$ also contributed to the difficulty for Western countries of establishing normal trade relations with the new state.

Although the basic policy of strict control of foreign trade mandated elimination of private trading, the People's Republic initially relied upon private concerns to organize a substantial portion of its foreign trade. These concerns possessed the experience, trained personnel, and established connections with foreign firms necessary to successfully carry out such a task. To cope with the difficult situation created by the embargo and other restrictions imposed by the United States and its allies, several ad hoc measures were taken by the Chinese government. These included (1) encouragement of direct dealings between private traders and their foreign counterparts in order to acquire essential commodities, (2) institution of a barter system, using available domestic products in exchange for foreign goods, and (3) maximum utilization of the special circumstances of various regions to promote import and export trade on a local basis in order to overcome the restrictions imposed by the embargo.

When these measures proved inadequate to produce the desired results, China moved even closer to the U.S.S.R. and Eastern Europe, and looked to countries in that region for the major part of its import and export trade. This explains the steady and dramatic increase in the volume of Chinese trade with the U.S.S.R. and Eastern Europe during this period. It was also during

\footnotetext{
${ }^{17}$ Mao Tse-tung stated that "all Chinese without exception must lean to the side of imperialism or to the side of socialism. Sitting on the fence will not do, nor is there a third road." 4 SELECTED Works of MaO TSE-TUNG, supra note 3 , at 415 .

${ }^{18}$ COCOM is formally known as the International Coordinating Committee on Strategic Trade with Communist Countries. It was formed by the Western powers and Japan to control trade with the communist countries. CHINCOM stands for China Coordinating Committee, a group formed by COCOM when China entered the Korean War in 1952.
} 
this period that the People's Republic of China and the U.S.S.R. entered into agreements for the joint operation of civil aviation between the two countries and the exploration of petroleum and other minerals in the Sinkiang province. ${ }^{19}$

The inability of the Western nations to maintain a united front in the trade embargo against China, and Chinese success in obtaining strategic and industrial materials from communist and other Asian countries in spite of the embargo combined to prove the futility of the United Nations economic sanctions. During the latter part of this period, there was a gradual expansion of Chinese foreign trade as a result of the establishment of trade relations between China and an increasing number of noncommunist nations. Aggressive export efforts and strict control over imports resulted in a substantial improvement in China's balance of payments. ${ }^{20}$ Foreign exchange earned in foreign trade further strengthened China's trading position in the free markets of the world and enabled it to become less dependent on the communist bloc for trade partners.

The second phase in the evolution of Chinese foreign trade policy is marked by a gradual expansion of trade with noncommunist or even "imperialist," countries. This development was precipitated to a substantial extent by the sudden withdrawal of Soviet technicians and by the Soviet Union's unilateral termination of its participation in all projects of industrial development in China.

In a report on the 1960 Draft Plan for the People's Economy submitted to the Second Session of the Second National People's Congress on March 30, 1960, Li Fu-ch'un, then Vice-Premier and Chairman of the National Planning Commission, said:

Following the continuous leap forward of the people's economy, foreign trade for 1960 will also continue its upward trend. Our foreign trade work should be based primarily on self-reliance supplemented by our efforts to gain foreign assistance, and adherence to the principal goal of actively supporting the great leap forward of industrial and agricultural productions. We should, within the framework of this principal goal and in the spirit of internationalism, further strengthen our trade and economic cooperation with various fraternal socialist countries to promote mutual economic advancement. We should, on the basis of equality, mutual benefit, and reciprocal exchange, develop our economic and trade relations with Asian, African, and Latin American countries. In regard to western capitalist countries, we are also willing to develop trade relations with them on the basis of equality and mutual benefit, but we must resolutely oppose all the discriminatory measures adopted by certain western countries against us in the area of trade. ${ }^{21}$

Since 1960, the P.R.C. has substantially increased its trade with countries outside of the communist bloc, both in volume and in the number of trade partners, putting an end to its policy of "leaning to one side." The admission

\footnotetext{
${ }^{19}$ See 1 Chung yang tS'ai Ching Cheng tS'E fa liNg hui PIEN 794-95 (1950). See also the editorial in Jen min jih pao, Apr. 5, 1950.

${ }^{20}$ According to a United Nations publication, between 1954 and 1956 the P.R.C. achieved a substantial gain from its trade with Asian countries. See U.N. Dep'r of Economic and Social AfFairs, 1956 World Economic SuRvey 249 (UN Doc E/2982, ST/ECA/44, 1957).

${ }^{21} 11$ FKHP 25-26 (1960).
} 
of the People's Republic of China into the United Nations in 1971 and the Nixon visit in early 1972 further enhanced the country's international prestige and prompted many countries to establish diplomatic relations with China, thus providing it with an ever-widening circle of potential trade partners. The gradual erosion of the trade embargo has effectively removed the necessity of "leaning to one side" with respect to foreign trade. According to the China Daily News, a New York-based Chinese language newspaper favorably oriented toward the P.R.C., Peking was trading with more than 150 countries by $1973 .^{22}$ The total value of its imports and exports in 1972 was said to be 48.4 per cent higher than in 1965, the year before the Cultural Revolution. ${ }^{23}$

During the second period of its foreign trade, Peking has thus assigned less weight to political factors in its choice of trading partners. Although political considerations will remain a factor in its foreign trade activities, it is unlikely that China will permit such considerations to overshadow its economic interests. In the foreseeable future, China will most likely avoid permitting any country or bloc to occupy a predominant position in its trade for political reasons alone. Rather, as many trade partners as possible will be sought on the most favorable terms obtainable. In short, Chinese trade has been, and will continue to be, conducted in a businesslike manner.

It seems clear that the government will continue to exercise strict control over Chinese foreign trade and to prohibit the use of its foreign exchange reserves to import consumer or other nonessential goods. A balance between imports and exports on a year-to-year basis will also continue as a goal. That goal, however, will not become a rigid self-imposed restriction on China's own economic growth. Rather, China will probably accept, or even seek, foreign credit, provided the terms are favorable and no political strings are attached.

\section{II}

\section{Foreign Trade Apparatus}

Following the establishment of the People's Republic of China, a new foreign trade structure was created to conduct its trade activities with other countries as a part of the overall plan of economic reform. The new economic order required that foreign trade, together with all other aspects of the national economy, be subject to central planning and direct control by the government. However, foreign trade was initially given a very low priority. There was no Ministry of Foreign Trade in the Government Administration Council although many other units of comparable importance were accorded ministerial stature. Instead, a Bureau of Foreign Trade was established as one of the component units of the Ministry of Trade. ${ }^{24}$ It was not until after the 1952 International Economic Conference in Moscow, at which China launched a major trade offensive, that a separate Ministry of Foreign Trade was created, answerable directly to the Government Administration Council. ${ }^{25}$

\footnotetext{
${ }^{22}$ China Daily News, Jan. 30, 1974.

${ }^{23}$ China Daily News, Dec. 26, 1973.

${ }^{24}$ See Provisional Regulations for the Control of Foreign Trade, art. 2, in I FLHP 337 (1952).

${ }^{25}$ See Jen min jih pao, Apr. 4, 1952.
} 
Although China's foreign trade apparatus has undergone various minor modifications during the past twenty-two years, its basic structure remains substantially unchanged. Its various organs may be grouped into two major categories-administrative and business. The principal administrative organs are the Ministry of Foreign Trade and its subordinate organs, and the China Council for the Promotion of International Trade and its subordinate organs. The business organs consist of the various state-owned foreign trade corporations. In addition, the Chinese government also maintains certain foreign trade organs outside China.

\section{A. Ministry of Foreign Trade}

According to the 1950 Provisional Regulations for the Control of Foreign Trade ${ }^{26}$ the Ministry of Foreign Trade is to exercise three major functions. These are: (1) approval and registration of importers and exporters (a function which was important at the time because of the existence of private enterprises and their participation in import and export activities); (2) approval and licensing of import and export transactions; and (3) fixing prices of import and export commodities. In addition to these functions, the Ministry of Foreign Trade also is to formulate the master plan of foreign trade, approve and supervise the business and financial plans of the various foreign trade corporations, allocate funds and inventories, and draft laws and regulations pertaining to foreign trade.

The Ministry of Foreign Trade has divided China's trading partners into four groups on the basis of geography and politics and has established within the Ministry four Bureaus, each in charge of trade with countries within its respective group. The First Bureau is in charge of trade with the U.S.S.R., North Korea, North Vietnam, and Outer Mongolia; the Second Bureau supervises trade with communist countries in Eastern Europe; the Third Bureau is in charge of trade with noncommunist Europe, America, and Australia; and the Fourth Bureau regulates trade with Africa and the noncommunist Asian nations. Aside from these four Bureaus, which collectively control Chinese trade with all countries of the world, there are two major units within the Ministry of Foreign Trade which play important roles in the foreign trade. They are the Commodities Testing and Inspection Bureau and the Customs Administration.

\section{Commodities Testing and Inspection Bureau}

The Commodities Testing and Inspection Bureau has established either branch offices or sub-branches at points of entry and exit for import and export commodities, major inland collection and distribution points for such commodities, major production areas, and major transshipment stations to carry out the functions prescribed by the Provisional Regulations for the Testing and Inspection of Import and Export Commodities. ${ }^{27}$ All import and

\footnotetext{
${ }^{26} 1$ FLHP 337-38 (1952).

${ }^{27}$ See Provisional Regulations for Testing and Inspection of Import and Export Commodities, art. 2, in 5 FLHP 71-73 (1955).
} 
export commodities falling within any one of the following categories are subject to mandatory testing and inspection: (1) commodities listed in the current Table of Commodities Subject to Testing and Inspection; (2) commodities required to be tested and inspected by the Commodities Testing and Inspection Bureau under foreign trade agreements entered into by state enterprises; (3) animals, plants, and their products required to be tested and inspected for the presence of harmful pestilence, disease, or bacteria; and (4) commodities required to be tested and inspected for detection of possible fraudulent substitution or adulteration. ${ }^{28}$

No commodities within any of these categories may be imported or exported without a certificate of approval issued by the Commodities Testing and Inspection Bureau or one of its branch offices or sub-branches. ${ }^{29}$ Aside from the mandatory testing and inspection of commodities falling within these four categories, purchasers or sellers in any export or import transaction may apply to the Commodities Testing and Inspection Bureau for an impartial determination of facts relating to the condition of commodities upon delivery, shipment, or acceptance. The Commodities Testing and Inspection Bureau shall, after due inspection, issue a certificate setting forth its findings. ${ }^{30}$

In the event that a party to a foreign trade transaction disagrees with the result of the Commodities Testing and Inspection Bureau's findings as to the quality of the commodities involved, a request for reinspection may be made. If such party disagrees with the results of the reinspection, he may apply for a review by the local government agency having jurisdiction over the local office of the Commodities Testing and Inspection Bureau. If the local government agency concludes that the complaint has merit, it will promptly appoint a committee to look into the matter and render a final decision. ${ }^{31}$

\section{Customs Administration}

At the Seventeenth Meeting of the Government Administration Council held on January 27, 1950, the policy regarding customs was established in accordance with the following goals:

The supervision and control of our country's customs work and foreign trade activities should have important effects on the recovery and development of the people's economy of our country. The customs tariff must protect our country's production and safeguard the competition of our domestic products with foreign merchandise. The Customs Administration must be a centralized, unified, independent and autonomous organ of the State. The Customs Administration shall be responsible for the direct supervision and control of the import and export of various commodities and currencies, the collection of customs duties, and the prevention of smuggling, in order to insure that our country will not again be subject to economic aggression by capitalist countries. ${ }^{32}$

Authorization was given for formation of a Committee of Experts under

\footnotetext{
${ }^{28}$ Id. art. 3.

${ }^{29} I d$. art. 4.

${ }^{30}$ Id. art. 5.

${ }^{31}$ Id. art. 9.

${ }^{32}$ See I FLHP 347 (1952).
} 
the Finance and Economic Commission of the Government Administration Council, which was to be charged with the task of formulating new tariff schedules for both import and export commodities. The Committee of Experts was formed, consisting of a representative from each of the following ministries: Trade, Finance, Heavy Industry, Railway, Agriculture, Communications, Food Industry, Post and Telegraph, Fuel Industry, Textile Industry, Light Industry, and the Customs Administration. A representative of the Finance and Economic Commission of the Government Administration Council was designated Chairman of the Committee of Experts.

The Government Administration Council also spelled out several basic principles for the guidance of the Committee of Experts in carrying out its mandate of formulating new tariff schedules. These included:

(1) With respect to manufactured and semi-finished goods that can be produced in large quantities domestically and such goods that potentially can be produced in the future, the import tariff for such goods should be higher than the difference between the cost of such goods and the cost of similar domestic products in order to protect the national industry.

(2) With respect to luxury goods and nonessential goods, the import tariff should be even higher.

(3) With respect to equipment, machinery, and materials for production that cannot be produced or cannot be produced in sufficient quantities domestically, and with respect to industrial raw materials, agricultural machinery, foodstuff seeds, and fertilizer, there should be either low duties or none at all.

(4) With respect to all essential scientific books and periodicals, materials for the prevention and treatment of agricultural pestilence, and certain drugs that cannot be produced domestically or for which domestic drugs cannot be substituted, there should either be no import duties or such duties should be reduced.

(5) There should be two separate customs tariff schedules for imports-an ordinary and normal customs tariff schedule applicable to countries that have signed treaties of commerce or trade agreements with the People's Republic of China, and a higher tariff schedule applicable to those countries that have not entered into such treaties or agreements.

(6) In order to promote the production of such goods for export, there should be very low duties for all semi-finished goods and industrial materials, or in some cases, no duties at all. ${ }^{33}$

Prior to 1953, the Customs Administration was an independent unit directly under the Government Administration Council. In 1953, pursuant to a decision of the Government Administration Council, the Customs Administration lost its independent status and became a subordinate unit of the Ministry of Foreign Trade, subject to its control and supervision. ${ }^{34}$ It has established, in various parts of the country, a number of branch offices and sub-branches to carry out its functions. These functions currently consist of the examination and inspection of all merchandise crossing the borders of China, the enforce-

\footnotetext{
${ }^{33} \mathrm{Id}$.

${ }^{34}$ See Decision of the Government Administration Council on the Merger of Customs and Foreign Trade Organs, in 4 FLHP 8-9 (1955).
} 
ment of all rules and regulations pertaining to warehouses and piers for import and export goods, the collection of customs duties and other revenues provided by law, the prevention of smuggling, and the performance of all other customs functions. ${ }^{35}$

The branch offices and sub-branches of the Customs Administration, in addition to being subject to the guidance and control of the central government, are also subject to the supervision of local authorities. The extent to which local supervision complements central control, and the areas of customs work in which these local authorities may exercise their supervisory authority have never been clearly spelled out, and hence have given rise to considerable difficulty. ${ }^{36}$ Under the Government Administration Council Directive of September $5,1955,{ }^{37}$ local customs offices shall be subject to the "dual guidance" (shuang chung ling tao) of the Ministry of Foreign Trade and the Provincial or Municipal People's Committee of the province or municipality in which the customs offices are located. They are also under the "direction" (chih tao) of the Foreign Trade Bureau of their respective province or municipality. ${ }^{38}$ Matters relating to customs policy, direction, laws, decrees, rules, regulations, and systems are to be decided by the central government. Local authorities are responsible for supervision of the implementation of these matters by the customs offices. Urgent matters of a local nature within the purview of the purpose, policy, laws, and decrees of the central government as well as matters relating to cooperation and coordination between local customs offices and other local government organs are to be handled by local authorities. Professional training of customs cadres is the responsibility of the Ministry of Foreign Trade, while political, theoretical, and cultural studies are to be handled by the local party and government.

In addition to the Commodities Testing and Inspection Bureau and the Customs Administration, mention should be made of the College of Foreign Trade, another unit of the Ministry of Foreign Trade. This unit is a college level educational institution for the training of foreign trade personnel. According to the Guide to Admission into Schools of Higher Education published by the Chinese Ministry of Higher Education in 1958, the College of Foreign Trade offers a five-year program of study ${ }^{39}$ Students seeking admission into the College

${ }^{35}$ See Experimental Regulations Governing the Organization of the Customs Administration, art. 10, in 1 FLHP 345-46 (1952). The Experimental Regulations were superseded by the Provisional Customs Law of the P.R.C., adopted by the Government Administration Council at its 77th meeting and promulgated on April 18, 1951, to take effect on May 1, 1951. In contrast to the Experimental Regulations, which contained only 15 articles, the Provisional Customs Law is a more elaborate piece of legislation, consisting of 217 articles. It deals with the organization of the Customs Administration, the supervision and control of movement of goods in and out of the country, the supervision and control of goods in transit or for transshipment, the examination, taxing, safekeeping, and release of import and export goods, the control of international parcel post, the release of persons and their baggage in and out of the country, and the handling of cases involving smuggling or other violations.

${ }^{36}$ See Report of Kung Yuan, Director of Customs, to the 77th meeting of the Government Administration Council, Mar. 23, 1951, in 3 CHUNG YANG TS'AI CHING CHENG TS'E FA LING HUI PIEN 451-56 (1952).

372 FKHP 594-95 (1956).

${ }^{38}$ The distinction between guidance (ling tao) and direction (chih tao) has not been made clear.

${ }^{39}$ In addition to courses in political science, economics, and political theory, the curriculum 
of Foreign Trade must possess good "political quality," and a certain level of proficiency in a foreign language. ${ }^{40}$ Many of the individuals now involved in Chinese foreign trade received their training at the College of Foreign Trade.

\section{B. The China Council for the Promotion of International Trade}

The status of the China Council for the Promotion of International Trade (CCPIT) has never been made clear. It came into existence after the 1952 Moscow International Economic Conference ${ }^{41}$ for the avowed purpose of providing a nongovernmental vehicle for the promotion of foreign trade. It purports to be a "social organization"-an association of prominent individuals interested in foreign trade. Technically speaking, it is neither a governmental agency nor a state-owned trading corporation. However, it does play a significant role in foreign trade activities and has frequently engaged in trade negotiations with foreign business groups or organizations, especially those of countries having no diplomatic relations with China.

Within the CCPIT are the following departments: (1) the General Administrative Office, responsible for attending to the day-to-day administrative affairs of the Council, (2) the Liaison Department, charged with fostering relations between China's foreign trade organs and organs of foreign trade in other countries, organizing Chinese nongovernmental economic and trade delegations for tours abroad, receiving foreign nongovernmental economic and trade delegations in China, and participating in nongovernmental economic conferences, (3) the Exhibits Department, in charge of Chinese economic and trade exhibits abroad, (4) the Department of Foreign Exhibits, which receives and makes necessary arrangements for foreign economic and trade exhibits held in China, (5) the Publicity Department, which publicizes foreign trade both in China and abroad, and (6) the Legal Affairs Office, which clears maritime losses, acts as agent for foreign concerns in applying for registration of trademarks in China, and certifies foreign trade documents. ${ }^{42}$

Also within the CCPIT are two arbitral bodies-the Foreign Trade Arbitration Commission and the Maritime Arbitration Commission. These two arbitration organizations were established pursuant to decisions of the Government Administration Council. ${ }^{43}$ Both the organization and the functions of the CCPIT

of the College of Foreign Trade includes the following major courses: National Economic History, Economic Geography, National Economic Plans, Economics of Trade, International Trade, Organization and Technique of Foreign Trade, World Commodities Market, International Settlement of Accounts and Supply of Foreign Trade Capital, Foreign Trade Accounting and Analysis of Economic Activities, Foreign Trade Transportation, Import-Export Commodities, Customs Work, Civil Laws of the P.R.C. and of the U.S.S.R., Foreign Civil and Commercial Laws, and International Law. Heavy emphasis is placed on the teaching of foreign languages, with every student required to learn at least one foreign language. Approximately one-third of the total class hours are devoted to this study.

40 See 1967 Fei ch'ing nien pao (Yearbook on Chinese Communism) 1069.

${ }^{41}$ See 1 P. Tang, Communist China Today 628 (2d ed. 1961).

42 See KUO GHI MAO I CHIH SHIH (KNOWLEdGe OF INTERNATIONAL TRADE) 66-67 (1973).

${ }^{43}$ See the Decision of the Government Administration Council, made at its 215th meeting on May 6, 1954, to establish a Foreign Trade Arbitration Commission in the China Council for the Promotion of International Trade. 1956 Tur waI MaO I 8. See also the Decision of the State Council, 
seem to indicate that as a practical matter it must be treated as a quasi-official organ performing certain public functions under the guidance and control of the government, although juridically its acts are not binding upon the state.

The CCPIT has conducted many trade fairs in China and participated in trade fairs and industrial exhibitions in various foreign countries as well. In addition to branches in Shanghai, Canton, Tientsin, Nanking, Hangchow, Dairen, Mukden, Harbin, Taiyuan, and Wuhan, it has resident trade representatives stationed in foreign countries, such as Austria, Italy, Peru, and Tanzania. ${ }^{44}$ The functions of CCPIT's two arbitral commissions will be considered in more detail below.

\section{Foreign Trade Arbitration Commission}

On May 6, 1954, the Government Administration Council, at its 215th meeting, established within the CCPIT a Foreign Trade Arbitration Commission (FTAC) to resolve controversies arising out of foreign trade transactions in cases where the agreement between the parties provides for arbitration. ${ }^{45}$ At the same time, the CCPIT was authorized to formulate rules of procedure for the arbitration of disputes arising out of foreign trade transactions. The Commission may have from fifteen to twenty-one members, to be selected by the CCPIT from among persons with special knowledge or experience in foreign trade, commerce, industry, agriculture, transportation, insurance, and law. The members are to elect a chairman and two vice-chairmen. Arbitration proceedings are to commence upon the application of one or both parties to the dispute, and may be conducted by either a single arbitrator or a three-man board. At the arbitration proceedings the parties may be represented by agents (tai $l i j e n$ ), who may be nationals of either the P.R.C. or of a foreign country. These agents may, but need not, be lawyers. The FTAC may, in cases of necessity and for the protection of the interests of the parties, order provisional measures with respect to goods or title to property of the parties. The Commission may charge a fee not to exceed one per cent of the amount of the claim to defray expenses in connection with the arbitration. The award rendered by the Commission is final and is not subject to judicial review. If the losing party fails to carry out its obligations under the award, the other party may petition the People's Court for enforcement of the award according to law.

Provisional Rules of Procedure of the FTAC were adopted by the CCPIT at its fourth meeting, held on March $31,1956 .{ }^{46}$ Under these Rules, arbitration hearings are to be conducted in open court unless either the arbitrator or the arbitration board, at its discretion and upon the request of one or both parties, decides to hold closed sessions. This provision is contrary to the general practice prevailing in most noncommunist countries where arbitration proceedings are generally held in camera. Article 27 of the Provisional Rules ex-

made at its 82 nd meeting on Nov. 21, 1958, to establish a Maritime Arbitration Commission in the China Council for the Promotion of International Trade. 8 FKHP 177 (1959).

44 See 6 Fei ch'ing yen Chui (Studies on Chinese Communism) 74 (1972).

451956 TUI WAI MaO I 8.

46 Id. at 9- 11 . 
pressly authorizes the arbitrator or the arbitration board to consult experts on questions of a technical nature or matters concerning custom and usage of a particular trade. Under article 29, decisions of the arbitration board are to be made by a majority vote, but the dissenter has the right to file a minority opinion.

\section{Maritime Arbitration Commission}

The Maritime Arbitration Commission (MAC) was authorized by a resolution of the State Council adopted at its eighty-second meeting, held on November 21, 1958. ${ }^{47}$ Basically, the Commission performs the functions of a court exercising admiralty jurisdiction. The only difference is that its jurisdiction is based on voluntary contractual submission of disputes. The three classes of disputes the Commission is authorized to handle are: (1) disputes over compensation for services in rendering assistance to another vessel when the crafts involved are either two seagoing vessels or a seagoing vessel and a river craft, (2) disputes arising out of collisions between two seagoing vessels or between a seagoing vessel and a river craft, or disputes arising out of damages caused by seagoing vessels to port structures or facilities, and (3) disputes regarding charter-parties and agency for seagoing vessels, freight (when based on freight agreements, bills of lading, or other shipping documents), and marine insurance. ${ }^{48}$

\section{State Foreign Trade Corporations}

When the People's Republic of China was established in 1949, a decision was made to gradually eliminate private trading organizations as a part of its program of economic transformation, so that all foreign trade transactions would ultimately be handled by state corporations under the direct control and supervision of the government pursuant to a master plan. Initially, six state foreign trade corporations were authorized to be established under the Ministry of Trade. They were the Bristles Corporation, the Native Produce Export Corporation, the Oils and Fats Corporation, the Import Corporation, the Tea Corporation, and the Minerals Corporation. ${ }^{49}$ Five more were soon added to the list. These were the China Petroleum Corporation, the China Egg Products Corporation, the China Silk Corporation, the China Skin and Fur Corporation, and the China Industrial Material and Equipment Corporation. In March, 1951, the China Import Corporation was expanded and reorganized to become the China Import and Export Corporation. In June of the same year, the Bristles, the Skin and Fur, and the Egg Products Corporations were consolidated to form the China National Animal By-Products Corporation. In order to step up the purchase of native products for export, the P.R.C. established additional export corporations beginning in 1954. They were: the China National Foodstuffs Export Corporation, the China National Cereals and Oils

\footnotetext{
${ }^{47} \mathrm{Id}$.

${ }^{48} \mathrm{Id}$.

49 See the Government Administration Council Decision, adopted at its 23rd meeting on Mar. 10, 1950, concerning the consolidation of state trading activities, in 1 FLHP 325-28 (1952).
} 
Export Corporation, the China Silk Export Corporation, and the China Miscellaneous Articles Export Corporation. These corporations continued to undergo mergers, reorganizations, and other changes so that immediately prior to the Cultural Revolution fourteen state foreign trade corporations existed. ${ }^{\mathbf{5 0}}$ More recently, however, the number of foreign trade corporations has been reduced by mergers so that today only eleven are in existence. ${ }^{51}$ All of these corporations have branches in key cities throughout China, with the exception of the International Bookstore which maintains no branches but uses the Peace Bookstore (Ho P'ing Shu Tien) in Hong Kong as its agent.

The legal status of these foreign trade corporations is similar to that of their counterparts in the Soviet Union. Technically, they are separate legal entities and not government organs. Although they are neither producers nor final users of the commodities they purchase or sell, they act not as agents, but as principals. They are capable of acquiring legal rights and assuming legal obligations in their own names and may sue or be sued. Their obligations are not the obligations of China and are backed only by their own resources-the amount of capital and operating funds appropriated to them by the government plus whatever retained earnings they may have. Each foreign trade corporation is a separate accounting unit and is operated as a separate enterprise.

Nevertheless, because each of these foreign trade corporations derives its existence from decisions made by the government, receives its mandate and working capital from the government, functions within prescribed limits set by the government, and is constantly supervised by the Ministry of Foreign Trade, each is in essence an arm of the government performing a public function. Personnel of these corporations are appointed by and serve at the pleasure of the government; the financial and business plans of the corporations are subject to governmental scrutiny and approval; and their funds and other properties are at the disposal of the government. From all of these facts, it seems quite clear that the separate entity concept is more fictional than real.

${ }^{50}$ See 1966 TuI waI MaO I. The fourteen state foreign trade corporations are: the Chinese National Cereals, Oils, and Foodstuffs Import-Export Corporation, the China National Arts and Crafts Import-Export Corporation, the China National Native Produce and Animal ByProducts Import-Export Corporation, the China National Textiles Import-Export Corporation, the China National Garments Import-Export Corporation, the China National Light Industrial Products Import-Export Corporation, the China National Chemicals Import-Export Corporation, the China National Machinery Import-Export Corporation, the China National Metals and Minerals Import-Export Corporation, the China National Complete Plants Export Corporation, the China National Foreign Trade Transportation Corporation, the China National Chartering Corporation, and the International Bookstore.

51 The eleven are: the China National Cereals, Oils, and Foodstuffs Import-Export Corporation, the China National Chemicals Import-Export Corporation, the China National Light Industrial Products Import-Export Corporation, the China National Machinery Import-Export Corporation, the China National Metals and Minerals Import-Export Corporation, the China National Native Produce and Animal By-Products Import-Export Corporation, the China National Textiles Import-Export Corporation, the China National Complete Plant Export Corporation, the International Bookstore, the China National Chartering Corporation, and the China National Foreign Trade Transportation Corporation. In addition to these eleven, there are two minor corporations which engage in specialized aspects of foreign trade: the China Film Distribution Corporation, which handles the importing of foreign films and the exporting of Chinese films, and the China Stamp Corporation. 
Each of these foreign trade corporations may operate only within prescribed limits. It may deal only in a particular category of commodities under a master plan. It conducts negotiations and enters into contracts only for the purchase or sale of commodities that fall within its jurisdiction. As a matter of internal decision-making, it is not clear how far up the hierarchical ladder an import or export proposal must go before a final decision is made. Some foreign trade agreements have been signed by the Premier himself, some by a Vice-Premier, others by the Minister or a Vice-Minister of Foreign Trade, and still others by the "responsible person" of the particular foreign trade corporation involved. Apparently, the decision-maker in a given transaction does not necessarily sign the resulting foreign trade agreement. Rather, the individual who actually signs may be dictated by protocol.

\section{Foreign Trade Organs Abroad}

Chinese foreign trade organs abroad may be grouped into four categories: the Trade Counselors appointed by the Ministry of Foreign Trade and stationed in embassies abroad, trade delegations stationed in countries accepting Chinese economic aid and Economic Counselors in embassies abroad (both appointed by the CCPIT), the unofficial trade representatives of the CCPIT stationed in countries having no diplomatic relations with China, and firms established in Hong Kong and Macao by state foreign trade corporations as their designated agents. ${ }^{52}$ The organs in the first three categories perform a variety of functions in the area of foreign trade, such as promotion of sales for the foreign trade corporations, furnishing local businesses with information on Chinese markets, issuance of import licenses, and liaison between the various foreign trade corporations and the local business community. Those in the last category serve as branches of particular state trading corporations.

\section{ConCLUSION}

An understanding of the foreign trade policy and apparatus of China will facilitate the promotion of trade, and thereby improve relations between the P.R.C. and other members of the international community. In a planned economy, it is obvious that foreign trade must be placed under government control. For a nation that has been subject to foreign economic exploitation for a century, China's policy of self-reliance and its insistence upon a tight

\footnotetext{
52 In order to facilitate direct business transactions, the P.R.C. has established in both Hong Kong and Macao a number of trading firms as the designated agents of various foreign trade corporations. In reality they are branches of the state foreign trade corporations. Those in Hong Kong include the Wu Feng Company (Wu Feng Hang), which is the agent of the China National Cereals, Oils, and Foodstuffs Import-Export Corporation, and the Hua Jun Corporation (Hua Jun Kung Szu), which is the agent for eight foreign trade corporations. It represents the China National Native Produce and Animal By-Products Import-Export Corporation, the China National Light Industrial Products Import-Export Corporation, the China National Textiles Import-Export Corporation, the China National Chemicals Import-Export Corporation, the China National Machinery ImportExport Corporation, the China National Metals and Minerals Import-Export Corporation, the China National Foreign Trade Transportation Corporation, and the China National Chartering Corporation. In Macao, the Nan Kuang Trading Corporation (Nan Kuang Mao I Kung Szu) acts as agent for most of these same foreign trade corporations. See WANG LI-YEN, KuNG FEI TUI WAI MAO I yen PIEN (Evolution of Communist China's Foreign TRADE) 25-26 (1967).
} 
rein on all foreign trade transactions are not difficult to understand. By virtue of its control over production and distribution of all domestic products and resources, licensing of imports and exports, foreign exchange control, and centralized planning of import and export trade, China is in a strong bargaining position vis-à-vis its foreign trade partners. What takes place at the semiannual Canton Trade Fair provides vivid illustration of this superior bargaining position. Every year thousands of invited foreign manufacturers and potential buyers gather to compete with each other in their negotiations with Chinese representatives while the latter speak with one voice under a master plan.

In imports, China is able to engage in a practice known in the construction trade as "bid-shopping," using the lowest bid to force a higher bidder to reduce his bid even lower. A similar tactic can be used in export transactions by limiting the quantity available for export, thus creating an artificial shortage of a particular commodity in the world market.

Once a contract is signed, however, China may be expected to live up to its commitment scrupulously. In spite of the famous British Vickers-Zimmer, Ltd. case, ${ }^{53}$ and a few other unpleasant experiences of some businessmen in their dealings with the P.R.C., it is fair to say that the People's Republic of China has established a very good record in fulfilling its contract obligations regarding both delivery and payment. The state import-export corporations have, by and large, shown their willingness to abide by the generally accepted principles of commercial law in their external dealings. Whenever a dispute has arisen, they have almost always tried to resolve the matter by direct negotiations in a fair and equitable manner instead of resorting to high-handed, arbitrary measures or taking advantage of legalistic technicalities. Like any reputable businessman in a capitalist economy, China seems eager to maintain a good reputation in the international business community.

Nevertheless, there are certain risks inherent in China trade that should not be overlooked. It must be borne in mind that China has not yet enacted a comprehensive civil or commercial code, that technical and legal arguments will not get very far with the P.R.C. authorities, and that its judicial cadres are instructed to discharge their functions not as impartial arbiters guided by immutable legal precepts and a sense of fairness, but as agents of the state who have a duty to implement state policies. In addition, harsh and arbitrary interference by local authorities inside China, often triggered by recurrent internal political upheavals, may turn an otherwise profitable venture into a businessman's nightmare.

Finally, the expression "mutual benefit" as used by the People's Republic of

\footnotetext{
53 In November, 1964, Vickers-Zimmer, Ltd. and the China National Technical Corporation entered into a contract for the installation of a petrochemical factory in Lanchow, China. Two technicians sent by the British corporation to China to perform its part of the contract were accused of espionage. One technician was subsequently convicted and sentenced to serve a three-year prison term by the Intermediate People's Court of Lanchow; the other was expelled from China. In spite of a contract provision calling for arbitration in Stockholm in case of a dispute arising out of the contract, the Peking Municipal Intermediate People's Court pronounced its decision on July 3, 1968 , cancelling the contract. In addition, it ordered the British corporation to pay an indemnity of 650,000 British pounds to the China National Technical Corporation and to withdraw its personnel still in China within ten days. See 11 Peking Rev. 4 (1968).
} 
China must be understood in its broadest sense. To construe mutual benefit from a purely economic point of view would be to misunderstand it completely. For the contemporary Chinese, mutual benefit has reference to political benefit as well. While noncommunist traders are primarily concerned with economic gains, China's foreign trade decisions are greatly influenced by its long-range global political objectives. Though the effects of such long-range political considerations on trade policy have become less pronounced, they continue to be a significant factor in Chinese trade.

Of immediate concern is the current "criticize Lin, criticize Confucious" campaign, which may be the precursor of another cultural revolution. As a result of speculation that the campaign will curtail China's blossoming trade with the U.S. and Western Europe, senior Chinese trade officials in Peking are reported to have stated that imports and exports will actually increase in $1974 .{ }^{54}$ If such statements are reliable, agreements reached in November of 1973 between the National Council for U.S.-China Trade and the China Council for the Promotion of International Trade bode well for Sino-American trade. Those agreements include the first visit to the United States by a P.R.C. commercial delegation. The delegation, which is to be comprised of officials of CCPIT and selected state trading corporations, will visit the U.S. in 1974..55 If, however, Peking's assurances that the current campaign will have no effect on foreign trade prove unduly optimistic, the future of Sino-American trade is problematical.

${ }^{54}$ Washington Post, Mar. 8, 1974, $\S \mathrm{A}$, at 21, col. 4.

${ }^{55}$ See 1 China Exchange Newsletter No. 3, at 7-8 (1973-74). 